\title{
Eyelid Carcinoma cM1 TNM Finding v8
}

National Cancer Institute

\section{Source}

National Cancer Institute. Eyelid Carcinoma cM1 TNM Finding v8. NCI Thesaurus. Code C140474.

Eyelid carcinoma with distant metastasis. (from AJCC 8th Ed.) 